\title{
Cartilage Injury
}

National Cancer Institute

\section{Source}

National Cancer Institute. Cartilage Injury. NCI Thesaurus. Code C35606.

Trauma to cartilage. 